\title{
Comparison of Models in Assessing Relationship of Corn Yield with Plant Height Measured during Early- to Mid-Season
}

\author{
Xinhua Yin (Corresponding author), Ngowari Jaja \& M. Angela McClure \\ Department of Plant Sciences, the University of Tennessee \\ 605 Airways Blvd., Jackson, TN 38301, USA \\ Tel: 731-425-4750_E-mail: xyin2@utk.edu \\ Robert M. Hayes \\ West Tennessee Research and Education Center \\ The University of Tennessee, 605 Airways Blvd., Jackson, TN 38301, USA
}

Received: February 15, 2011 Accepted: March 26, 2011 doi:10.5539/jas.v3n3p14

\begin{abstract}
Relationship of corn (Zea mays L.) yield with plant height measured during early- to mid-season may possess the potential to be used to develop algorithms for guiding variable-rate $\mathrm{N}$ applications within a field. This study evaluated the performance of the linear, quadratic, square root, logarithmic, and exponential models in assessing the relationship of corn yield with plant height measured at three growth stages and four cropping systems for three years. The determination coefficient $\left(\mathrm{R}^{2}\right)$ values of these five models were generally similar at each growth stage within each cropping system and year or within each cropping system on the three-year combined data. Our results suggest that all these models could be used to describe the relationship of corn yield with plant height during early- to mid-season under different cropping systems and weather conditions, but the linear model may be the preferred model because of its simplicity.
\end{abstract}

Keywords: Corn, N Rate, Plant Height, Yield, Model, Cropping System

\section{A List of Abbreviations}

GDD, growing degree days;

NDVI, normalized difference vegetation index;

V6, 6-leaf growth stage;

V10, 10-leaf growth stage;

V12, 12-leaf growth stage.

\section{Introduction}

Plant height is a good measure of corn growth during vegetative development. It is affected by both crop and soil management factors. Corn produces taller plants at high plant population (Jonathan, et al., 2006). Soil moisture availability (Hussain et al., 1999), soil compaction, surface soil structure, and soil aggregation (Kladivko et al., 1986), fertilizer applications (Kapusta et al., 1996), and tillage system (Kladivko et al., 1986) also influence plant height of corn. In addition, plant height differs among corn cultivars (Rhoads and Stanley, 1973).

Plant height has been increasingly investigated during the past several years for its potential to be used to develop algorithms to guide high resolution variable-rate $\mathrm{N}$ applications within a field because plant height can be measured non-destructively and at high resolutions during early- to mid-season through ultra-sound distance sensing of the crop canopy (Katsvairo et al., 2003; Machado et al., 2002; Shrestha et al., 2002). If early- to mid-season plant height is a good predictor of corn yield, the integration of plant height sensing with variable-rate application and the Global Positioning System will enable on-the-go determination of N fertilizer requirements of different parts within a field, real-time applications of $\mathrm{N}$ at variable rates to meet those requirements, and precision treatment of each part of the field sensed without data pre-processing or previously determining the location within a field. Therefore, this non-destructive plant height-based system could minimize 
labor and cost on variable-rate $\mathrm{N}$ applications relative to the other precision $\mathrm{N}$ management systems such as grid sampling of soil and crop.

Compared with canopy normalized difference vegetation index (NDVI), another plant measure being used to develop algorithms for guiding variable-rate $\mathrm{N}$ applications within a field (Biermacher et al., 2006; Ortiz-Monasterio and Raun, 2007; Raun et al., 2001; Raun et al., 2002; Teal et al., 2006; Tubana et al., 2008), much less information is available about the relationship of corn yield with plant height (Katsvairo et al., 2003; Machado et al., 2002). Katsvairo et al. (2003) and Machado et al. (2002) both reported that plant height correlated with corn yields during early- and mid-season, but this correlation varied with locations and years.

Because $\mathrm{N}$ fertilizer recommendations for corn are based on yield goals in many areas, more investigations are needed to assess the relationship of yield with plant height of corn in order to make plant height sensing a reliable tool for predicting corn yield and thus assessing the $\mathrm{N}$ fertilizer requirements of different parts within a field. This relationship should be evaluated under different cropping systems and weather conditions. Meanwhile, the response of plant height to $\mathrm{N}$ application rates and the correlation of plant height with $\mathrm{N}$ application rate also need further investigation.

Unlike the association of corn yield with canopy NDVI (Moges et al., 2007; Teal et al., 2006), the relationship of corn yield and plant height has so far not been documented. Because corn yield increases with plant biomass, and plant biomass is positively related with plant height; it is assumed that corn yield increases as plant height increases within a certain range of plant height. Therefore, linear $\left(y=a+b^{*} x\right)$, quadratic $\left(y=a+b^{*} x+c^{*} x^{2}\right)$, square root $\left(y=a+b^{*} \sqrt{x}\right)$, logarithmic, $\left(y=a+b^{*} \ln x\right)$, and exponential $\left(y=a^{*} e^{b^{* x}}\right)$ models are possible models that can be used to describe the relationship of corn yield with plant height. The objectives of this study were to evaluate the response of corn plant height to $\mathrm{N}$ application rates and the performance of five different regression models (linear, quadratic, square root, logarithmic, and exponential) in assessing the relationship between corn yield and plant height measured at key growth stages during early- to mid-season under four different cropping systems.

\section{Materials and Methods}

\subsection{Site Description and Experimental Design}

Nitrogen trials were conducted on the University of Tennessee's Research and Education Center at Milan, TN from 2008 through 2010. Each trial was comprised of six N rate treatments: 0, 62, 123, 185, 247, $308 \mathrm{~kg} \mathrm{~N} \mathrm{ha}^{-1}$, which were implemented each year in a randomized complete block design with four replicates. These six $\mathrm{N}$ treatments were evaluated for three years under four different corn cropping systems which were continuous corn, corn after soybean, corn after cotton, and irrigated corn after soybean. All three non-irrigated cropping systems were placed in the same field, while the irrigated system was arranged in an adjacent field each year.

The soil for the three non-irrigated cropping systems was categorized as Grenada (fine-silty, mixed, active, thermic Oxyaquic Fraglossudalfs) in all three years. The soil for the irrigated system was classified as Loring (fine-silty, mixed, active, thermic Oxyaquic Fragiudalfs) in three seasons. All fields used in this study had over 10 years of continuous no-tillage production history.

\subsection{Initial Soil Properties and Crop Management}

A 10-core composite soil sample was taken randomly with a $2.5-\mathrm{cm}$ diameter hand probe from the experimental area of each field in the $0-$ to $15-\mathrm{cm}$ depth during the preceding fall of each year. After the samples were air-dried, ground to pass through a 2-mm screen, and mixed thoroughly, they were analyzed by the University of Tennessee's Soil Testing Laboratory. Soil pH was measured in a 1:1 $\left(\right.$ soil: $\left.\mathrm{H}_{2} \mathrm{O}\right)$ solution (Watson and Brown, 1998). Soil available P and K were extracted with the Mehlich I method (Sims, 1989).

The field for the three non-irrigated cropping systems had a soil $\mathrm{pH}$ of 6.3 in 2008, 6.4 in 2009, and 6.1 in 2010; and had Mehlich I extractable P and K of 14 and $92 \mathrm{mg} \mathrm{kg}^{-1}$ in 2008, 42 and $107 \mathrm{mg} \mathrm{kg}^{-1}$ in 2009, and 23 and 84 $\mathrm{mg} \mathrm{kg}^{-1}$ in 2010, respectively, prior to experimentation. For the irrigated system, soil $\mathrm{pH}$ was 6.5 in $2008,5.9$ in 2009, and 5.8 in 2010; and Mehlich I extractable P and K levels were 26 and $76 \mathrm{mg} \mathrm{kg}^{-1}$ in 2008, 17 and $71 \mathrm{mg}$ $\mathrm{kg}^{-1}$ in 2009, and 11 and $56 \mathrm{mg} \mathrm{kg}^{-1}$ in 2010, respectively. Both P and K fertilizers were applied as needed each year according to the University of Tennessee's recommendations based on the above soil testing results (Savoy and Joines, 2010).

Nitrogen fertilizer was uniformly broadcast on the soil surface within seven days after corn planting as ammonium nitrate (34N-0P-0K) each year. Corn (c.v. Pioneer 33N58) was planted with a John Deere vacuum planter (John Deere, Moline, IL) in a 76-cm row width with six rows of corn per plot under no-tillage for all cropping systems on 22 April 2008, 17 April 2009, and 13 April 2010. The plots were $9.1 \mathrm{~m}$ long and $4.6 \mathrm{~m}$ 
wide. Fertilizer (except N) applications and weed, pest, and disease control were completed as needed according to the University of Tennessee's recommended management practices. Corn at the irrigated location was irrigated under a Valley linear irrigation system (Valmont Irrigation, Valley, NE). Water amounts for irrigation were based on the MOIST soil moisture management system (Leib, 2011) and were identical for all treatments.

\subsection{Plant Height Measurement and Yield Determination}

Plant height was measured with a meterstick by randomly selecting eight plants from the two center rows of each plot at growth stages of around the 6-leaf growth stage (V6) (11 June 2008 and 25 May 2010), the 10-leaf growth stage (V10) (19 June 2008, 17 June 2009, and 10 June 2010), and the 12-leaf growth stage (V12) (2 July 2008, 24 June 2009, and 16 June 2010). Average plant height was calculated for each plot within each cropping system-year.

After physiological maturity, the two center rows of corn were harvested from each plot for grain yield using a small plot combine with an automatic weighing scale and moisture meter. The three non-irrigated cropping systems were harvested on 9 September 2008, 9 September 2009, and 23 August 2010. The irrigated corn was harvested on 11 September 2008, 28 September 2009, and 23 August 2010. Grain yield was adjusted to moisture content of $155 \mathrm{~g} \mathrm{~kg}^{-1}$. Daily rainfall and air temperature were recorded on site for all three seasons. Growing degree days (GDD) from corn planting to harvest were calculated for each growing season with the method of Wiebold (2010).

\subsection{Statistical Analysis}

Regression of plant height measured at V6, V10, and V12 with $\mathrm{N}$ application rate was conducted with the GLM procedure of SAS for Windows V9 (2) (SAS Institute, Cary, NC). Regression analysis was conducted with plant height as the dependent variable and $\mathrm{N}$ application rate as the independent variable to examine the relationship between plant height and $\mathrm{N}$ application rate at V6, V10, and V12 for each cropping system-year. A quadratic model $\left(\mathrm{y}=\mathrm{a}+\mathrm{b}^{*} \mathrm{x}+\mathrm{c}^{*} \mathrm{x}^{2}\right)$ was employed in this analysis.

Regression analyses were conducted between corn yield and plant height measured at V6, V10, and V12 to assess the relationship of yield with plant height at V6, V10, and V12, respectively. Linear, quadratic, square root, logarithmic, and exponential models were used for these analyses. Regression analyses were conducted on the following two different types of data sets: Each cropping system-year, and each cropping system across all years. In this study, the determination coefficient $\left(\mathrm{R}^{2}\right)$ values were used to evaluate the strength of relationship between corn yield and plant height measured in early- to mid-season. The $\mathrm{R}^{2}$ value was calculated as the quotient of the sum of squares for regression divided by the corrected total sum of squares $\left(\mathrm{SS}_{\text {regression }} / \mathrm{SS}_{\text {corrected }}\right.$ total) for all models so that all the models are comparable. The GLM procedure in SAS was used for the linear, quadratic, square root, and logarithmic models. For the square root and logarithmic models, a new variable of square root $(\mathrm{x})$ and $\ln (\mathrm{x})$ was generated, respectively, before conducting the GLM analysis. The NLIN procedure in SAS was employed for the exponential model. Probability levels lower than 0.05 were designated as significant for all analyses.

\section{Results and Discussion}

Weather conditions varied among the three growing seasons in this study. The total rainfall from corn planting to harvest was 411, 582, and $907 \mathrm{~mm}$ for the non-irrigated cropping systems and 411, 698, and $907 \mathrm{~mm}$ for the irrigated corn in 2008, 2009, and 2010, respectively (Figure 1). The 2010 season received a higher amount of rainfall than the others. The non-irrigated and irrigated systems had the same rainfall except 2009 when the irrigated corn was harvested 19 days later than the non-irrigated corn. In addition, the irrigated corn received 156 $\mathrm{mm}$ of irrigation water from 17 June to 26 August in 2008, $83 \mathrm{~mm}$ of irrigation from 23 June to 13 August in 2009, and $177 \mathrm{~mm}$ of irrigation from 17 June to 12 August in 2010. The GDD for the growing season from planting to harvest was 1829,1858 , and 1844 in 2008, 2009, and 2010, respectively, for the non-irrigated cropping systems, and was 1858, 2111, and 1844 in 2008, 2009, and 2010, respectively, for the irrigated system. The three growing seasons had similar GDD for all the cropping systems over the three years except the irrigated one in 2009 which was harvested 19 days later than the other systems. However, the average daily air temperatures of June, July, and August were $25.5,26.6$, and $25.1^{\circ} \mathrm{C}$ in $2008,26.0,24.6$, and $24.5^{\circ} \mathrm{C}$ in 2009 , and 27.6, 27.6, and $27.9^{\circ} \mathrm{C}$ in 2010 , respectively (Figure 2). Overall, the 2009 season was somewhat cooler in July and August, and 2010 was hotter during June to August, compared with 2008.

\subsection{Regression of Plant Height with $N$ Application Rate}

Regression of plant height measured at the V6, V10, and V12 growth stages with $\mathrm{N}$ application rate were all statistically significant under a quadratic model in 2008, 2009, and 2010 in corn after soybean (Figures 3, 4, \& 5). Improvements of $\mathrm{R}^{2}$ values were frequently observed in this regression when the growing season progressed 
from V6 to V10 and to V12. Similar tendencies were observed in the regression of plant height with N application rate in continuous corn, corn after cotton, and irrigated corn (Table 1). Corn yields differed remarkably among the four cropping systems (Yin et al., 2011). Corn after soybean and corn after cotton both produced intermediate yields, continuous corn yielded the lowest, and irrigated corn had the highest yield. Our results indicate that the relationship of plant height with $\mathrm{N}$ application rate generally remains similar under different cropping systems.

The majority of the $\mathrm{R}^{2}$ values were above 0.50 at V6, V10, and V12 under the four cropping systems in all three years. For field trials, $\mathrm{R}^{2}$ value of 0.50 is sometimes used as the critical value to determine whether a regression is strong or not. If that criterion is used, our results suggest that the association of plant height with $\mathrm{N}$ application rate was strong in this study except V10 for continuous corn and V6 for irrigated corn in 2010. The generally strong regression of plant height with $\mathrm{N}$ application rate in this study is an indicator that plant height may be used as a viable measure to determine the $\mathrm{N}$ fertilizer requirements of different parts within a field, and thus be used to guide variable-rate $\mathrm{N}$ applications within a field of corn during early- to mid-season. Similarly, Taylor et al. (2007) reported a good relationship of canopy NDVI with N fertilizer rate in two cotton studies in Oklahoma.

\subsection{Comparison of Models in Assessing the Relationship of Corn Yield with Plant Height}

In continuous corn, the $\mathrm{R}^{2}$ values were similar for the linear, quadratic, square root, logarithmic, and exponential models at each growth stage each year no matter whether the regression of corn yield with plant height was strong or weak (Table 2). When the data were combined across the three years for each cropping system, these five models in general still had similar $\mathrm{R}^{2}$ values at each growth stage, even though the regression of yield and plant height was generally weaker compared with those in each individual year due to the confounding of year effects with the effects of $\mathrm{N}$ rate treatments. For corn after soybean, corn after cotton, and irrigated corn, the $\mathrm{R}^{2}$ values remained alike for these five models at each growth stage within each year and cropping system (Tables 3 , $4, \& 5)$. When the data were combined across all three years under each cropping system, the $\mathrm{R}^{2}$ values for these five models generally remained similar at each growth stage.

Overall, similar $\mathrm{R}^{2}$ values for the five models suggest that these five models have comparable performances in assessing the relationship of corn yield with plant height irrespective of growth stage, year, and cropping system. Since corn yields differed remarkably among these four cropping systems (Yin et al., 2011), and the rainfall and daily air temperatures varied noticeably among the three growing seasons (Figures $1 \& 2$ ) in this study; our results suggest that the performances of these five models remain comparable under different cropping systems and weather conditions.

As mentioned above, when the data were combined across all three years under each cropping system, the $\mathrm{R}^{2}$ values for this regression generally became weaker compared with those of each individual year at all growth stages (Tables 2, 3, 4, \& 5). Similarly, Chang et al. (2003) found that the $\mathrm{R}^{2}$ value for the regression of corn yield with multispectral and multidate reflectance was 0.78 and 0.91 for two different locations, but it went down to 0.47 when the data were pooled across the two locations. This was at least partially due to the differences in production conditions among locations and years (Yau and Hamblin, 1994).

\section{Conclusions}

Plant height measured at V6, V10, and V12 generally had a strong association with $\mathrm{N}$ application rate under continuous corn, corn after soybean, corn after cotton, and irrigated corn after soybean in all three years. This association could be described with a quadratic model. The generally strong relationship of plant height with $\mathrm{N}$ application rate is an indicator that plant height may be used as a viable measure to determine the $\mathrm{N}$ fertilizer requirements of different parts within a field, and thus be used to guide variable-rate $\mathrm{N}$ applications within a field on corn during early- to mid-season.

The $\mathrm{R}^{2}$ values of the linear, quadratic, square root, logarithmic, and exponential models were generally comparable in the regression of corn yield with plant height at each growth stage within each cropping system and year or within each cropping system on the three-year combined data. Our results suggest that these five models could all be used to assess the relationship of corn yield with plant height measured during early- to mid-season under different cropping systems and weather conditions, but the linear model may be the preferred model because of its simplicity.

\section{References}

Biermacher, J. T., Epplin, F. M., Brorsen, B. W., Solie, J. B., \& Raun, W. R. (2006). Maximum benefit of a precise nitrogen application system for wheat. Precision Agric., 7, 1-12. doi:10.1007/s11119-006-9017-6, http://dx.doi.org/10.1007/s11119-006-9017-6 
Chang, J., Clay, D. E., Dalsted, K., Clay, S., \& O’Neill, M. (2003). Corn (Zea mays L.) yield prediction using multispectral and multidate reflectance. Agron. J., 95, 1447-1453. doi:10.2134/agronj2003.1447, http://dx.doi.org/10.2134/agronj2003.1447

Hussain, I., Olson, K. R., \& Ebelhar, S. A. (1999). Impacts of tillage and no-till on production of maize and soybean on an eroded Illinois silt loam soil. Soil Tillage Res., 52, 37-49. doi:10.1016/S0167-1987(99)00054-9, http://dx.doi.org/10.1016/S0167-1987(99)00054-9

Jonathan, D. S., Stewart, A. M., \& Leonard, B. R. (2006). Comparative growth and yield of cotton planted at various densities and configurations. Agron. J., 98, 562-568. doi:10.2134/agronj2005.0181, http://dx.doi.org/10.2134/agronj2005.0181

Kapusta, G., Krausz, R. F., \& Matthews, J. L. (1996). Corn yield is equal in conventional, reduced, and no tillage after 20 years. Agron. J., 88, 812-817. doi:10.2134/agronj1996.00021962008800050021x, http://dx.doi.org/10.2134/agronj1996.00021962008800050021x

Katsvairo T. W., Cox, W. J., \& Van Es, H. M. (2003). Spatial growth and nitrogen uptake variability of corn at two nitrogen levels. Agron. J., 95, 1000-1011. doi:10.2134/agronj2003.1000, http://dx.doi.org/10.2134/agronj2003.1000

Kladivko, E. J., Griffith, D. R., \& Mannering, J. V. (1986). Conservation tillage effects on soil properties and yield of corn and soya beans in Indiana. Soil Tillage Res., 8, 277-287. doi:10.1016/0167-1987(86)90340-5, http://dx.doi.org/10.1016/0167-1987(86)90340-5

Leib, B. G. (2011). Management of irrigation systems in Tennessee (MOIST) spreadsheet. [Online] Available: http://bioengr.ag.utk.edu/weather/. Accessed 20 March, 2011.

Machado, S., Bynum, E. D., Jr., Archer, T. L., Lascano, R. J., Wilson, L. T., Bordovsky, J., Segarra, E., Bronson, K., Nesmith, D. M., \& Xu, W. (2002). Spatial and temporal variability of corn growth and grain yield: Implications for site-specific farming. Crop Sci., 42, 1564-1576. doi:10.2135/cropsci2002.1564, http://dx.doi.org/10.2135/cropsci2002.1564

Moges, S. M., Girma, K., Teal, R. K., Freeman, K. W., Zhang, H., Arnall, D. B., Holtz, S. L., Tubaña, B. S., Walsh, O., Chung, B., \& Raun, W. R. (2007). In-season estimation of grain sorghum yield potential using a hand-held optical sensor. Archives Agron. Soil Sci., 53, 617-628. doi:10.1080/03650340701597251, http://dx.doi.org/10.1080/03650340701597251

Ortiz-Monasterio, J. I., \& Raun, W. R. (2007). Reduced nitrogen and improved farm income for irrigated spring wheat in the Yaqui Valley, Mexico, using sensor based nitrogen management. J. Agric. Sci., 145, 1-8. doi:10.1017/S0021859607006995, http://dx.doi.org/10.1017/S0021859607006995

Pale, S., Mason, S. C., \& Galusha, T. D. (2003). Planting time for early-season pearl millet and grain sorghum in Nebraska. Agron. J., 95, 1047-1053. doi:10.2134/agronj2003.1047, http://dx.doi.org/10.2134/agronj2003.1047

Raun, W. R., Johnson, G. V., Stone, M. L., Solie, J. B., Lukina, E. V., \& Thomason, W. E. (2001). In-season prediction of potential grain yield in winter wheat using canopy reflectance. Agron. J., 93, 131-178. doi:10.2134/agronj2001.931131x, http://dx.doi.org/10.2134/agronj2001.931131x

Raun, W. R., Solie, J. B., Johnson, G. V., Stone, M. L., Mullen, R. W., Freeman, K. W., Thomason, W. E., \& Lukina, E. V. (2002). Improving nitrogen use efficiency in cereal grain production with optical sensing and variable rate application. Agron. J., 94, 815-820. doi:10.2134/agronj2002.0815, http://dx.doi.org/10.2134/agronj2002.0815

Rhoads, F. M., \& Stanley, R. L., Jr. (1973). Response of three corn hybrids to low levels of soil moisture tension in the plow layer. Agron. J., 65, 315-318. doi:10.2134/agronj1973.00021962006500020038x, http://dx.doi.org/10.2134/agronj1973.00021962006500020038x

Savoy, H. J., \& Joines, D. (2010). Lime and fertilizer recommendations for the various crops of Tennessee. Chapter II. Agronomic crops. [Online] Available: http://soilplantandpest.utk.edu/pdffiles/soiltestandfertrecom/chap2-agronomic_mar2009.pdf. Accessed 14 October, 2010.

Shrestha, D. S., Steward, B. L., Birrell, S. J., \& Kaspar, T. C. (2002). Plant height estimation using two sensing systems. ASAE Annual International meeting. 2002. CD-ROM. St. Joseph, MI.

Sims, J. T. (1989). Comparison of mehlich 1 and mehlich 3 extractants for $\mathrm{P}, \mathrm{K}, \mathrm{Ca}, \mathrm{Mg}, \mathrm{Mn}, \mathrm{Cu}$ and $\mathrm{Zn}$ in atlantic coastal plain soils. Commun. Soil Sci. Plant Anal., 20, 1707-1726. doi:10.1080/00103628909368178, http://dx.doi.org/10.1080/00103628909368178 
Taylor, R., Banks, J. C., Osborne, S., Sharp, T., Solie, J., \& Raun, W. R. (2007). In-season cotton management using real time sensors. 2007 Beltwide Cotton Conferences, New Orleans, LA. January 9-12, 2007.

Teal, R. K., Tubana, B., Girma, K., Freeman, K. W., Arnall, D. B., Walsh, O., \& Raun, W. R. (2006). In-season prediction of corn grain yield potential using normalized difference vegetation index. Agron. J., 98, 1488-1494. doi:10.2134/agronj2006.0103, http://dx.doi.org/10.2134/agronj2006.0103

Tubana, B. S., Arnall, D. B., Walsh, O., Chung, B., Solie, J. B., Girma, K., \& Raun, W. R. (2008). Adjusting midseason nitrogen rate using a sensor-based optimization algorithm to increase use efficiency in corn. J. Plant Nutr., 31, 1393-1419. doi:10.1080/01904160802208261, http://dx.doi.org/10.1080/01904160802208261

Watson, M. E., \& Brown, J. R. (1998). pH and lime requirement, in: Brown, J. R., (ed.) Recommended chemical soil test procedures for the north central region. NCR Research Publication No. 221. University of Missouri, Columbia, MO. pp. 13-16.

Wiebold, B. (2010). Growing degree days and corn maturity. [Online] Available: http://plantsci.missouri.edu/cornx/calculator/about.cfm. Accessed 14 October, 2010.

Yau, S. K., \& Hamblin, J. (1994). Relative yield as a measure of entry performance in variable environments. Crop Sci., 34:813-817. doi:10.2135/cropsci1994.0011183X003400030038x, http://dx.doi.org/10.2135/cropsci1994.0011183X003400030038x

Yin, X., McClure, M. A., Jaja, N., Tyler, D. D., \& Hayes, R. M. (2011). In-season prediction of corn yield using plant height under major production systems. Agron. J., 103:923-929. doi:10.2134/agronj2010.0450, http://dx.doi.org/10.2134/agronj2010.0450

Table 1. Relationship of plant height measured at V6, V10, and V12 with N application rate in continuous corn, corn after cotton, and irrigated corn during 2008 to 2010

\begin{tabular}{|l|l|l|l|l|l|l|l|}
\hline Cropping system & Growth stage & 2008 & \multicolumn{2}{l|}{2009} & \multicolumn{2}{l|}{2010} \\
\hline & & $\mathrm{R}^{2}$ & $\mathrm{Sig}$ & $\mathrm{R}^{2}$ & $\mathrm{Sig}$ & $\mathrm{R}^{2}$ & $\mathrm{Sig}$ \\
\hline Continuous corn & $\mathrm{V} 6$ & $0.74 \dagger$ & $* * *+$ & & & 0.70 & $* * *$ \\
\hline & $\mathrm{V} 10$ & 0.83 & $* * *$ & 0.88 & $* * *$ & 0.36 & $*$ \\
\hline & $\mathrm{V} 12$ & 0.81 & $* * *$ & 0.88 & $* * *$ & 0.90 & $* * *$ \\
\hline & & & & & & & \\
\hline Corn after cotton & $\mathrm{V} 6$ & 0.84 & $* * *$ & & & 0.57 & $* * *$ \\
\hline & $\mathrm{V} 10$ & 0.87 & $* * *$ & 0.73 & $* * *$ & 0.77 & $* * *$ \\
\hline & $\mathrm{V} 12$ & 0.87 & $* * *$ & 0.81 & $* * *$ & 0.85 & $* * *$ \\
\hline & & & & & & & \\
\hline Irrigated corn & $\mathrm{V} 6$ & 0.79 & $* * *$ & & & 0.21 & $*$ \\
\hline & $\mathrm{V} 10$ & 0.84 & $* * *$ & 0.77 & $* * *$ & 0.79 & $* * *$ \\
\hline & $\mathrm{V} 12$ & 0.90 & $* * *$ & 0.86 & $* * *$ & 0.88 & $* * *$ \\
\hline
\end{tabular}

$\dagger \mathrm{R}^{2}$, determination coefficient. Sig, significance.

$\ddagger^{*}$ and $* * *$ significant at 0.05 and 0.001 levels, respectively. 
Table 2. Model comparisons in assessing the relationship of yield with plant height measured at V6, V10, and V12 of continuous corn during 2008 to 2010

\begin{tabular}{|c|c|c|c|c|c|c|c|c|c|}
\hline \multirow[t]{2}{*}{ Growth stage } & \multirow[t]{2}{*}{ Model } & \multicolumn{2}{|c|}{2008} & \multicolumn{2}{|c|}{2009} & \multicolumn{2}{|c|}{2010} & \multicolumn{2}{|c|}{$\begin{array}{c}\text { Combined data } \\
(2008-2010)\end{array}$} \\
\hline & & $\mathrm{R}^{2}$ & Sig & $\mathrm{R}^{2}$ & Sig & $\mathrm{R}^{2}$ & Sig & $\mathrm{R}^{2}$ & Sig \\
\hline \multirow[t]{5}{*}{ V6 } & Linear & 0.50 & $* * * \dagger$ & & & 0.34 & $* *$ & 0.12 & $*$ \\
\hline & Quadratic & 0.53 & $* * *$ & & & 0.46 & $* *$ & 0.15 & $*$ \\
\hline & Square root & 0.51 & $* * *$ & & & 0.35 & $* *$ & 0.11 & $*$ \\
\hline & Logarithmic & 0.51 & $* * *$ & & & 0.37 & $* *$ & 0.10 & $*$ \\
\hline & Exponential & 0.47 & $* * *$ & & & 0.29 & $* *$ & 0.00 & Ns \\
\hline \multirow[t]{5}{*}{ V10 } & Linear & 0.64 & $* * *$ & 0.76 & $* * *$ & 0.26 & $*$ & 0.16 & $* * *$ \\
\hline & Quadratic & 0.65 & $* * *$ & 0.78 & $* * *$ & 0.27 & $*$ & 0.36 & $* * *$ \\
\hline & Square root & 0.64 & $* * *$ & 0.75 & $* * *$ & 0.26 & $*$ & 0.18 & $* * *$ \\
\hline & Logarithmic & 0.64 & $* * *$ & 0.73 & $* * *$ & 0.25 & $*$ & 0.19 & $* * *$ \\
\hline & Exponential & 0.64 & $* * *$ & 0.77 & $* * *$ & 0.27 & $*$ & 0.13 & $* *$ \\
\hline \multirow[t]{5}{*}{$\mathrm{V} 12$} & Linear & 0.71 & $* * *$ & 0.77 & $* * *$ & 0.74 & $* * *$ & 0.33 & $* * *$ \\
\hline & Quadratic & 0.72 & $* * *$ & 0.81 & $* * *$ & 0.82 & $* * *$ & 0.38 & $* * *$ \\
\hline & Square root & 0.70 & $* * *$ & 0.76 & $* * *$ & 0.73 & $* * *$ & 0.34 & $* * *$ \\
\hline & Logarithmic & 0.70 & $* * *$ & 0.75 & $* * *$ & 0.71 & $* * *$ & 0.35 & $* * *$ \\
\hline & Exponential & 0.72 & $* * *$ & 0.81 & $* * *$ & 0.81 & $* * *$ & 0.28 & $* * *$ \\
\hline
\end{tabular}

$\dagger \mathrm{R}^{2}$, determination coefficient. Sig, significance.

$t^{*}, * *$, and $* * *$ significant at $0.05,0.01$, and 0.001 levels, respectively. Ns, not significant at 0.05 level.

Table 3. Model comparisons in assessing the relationship of yield with plant height measured at V6, V10, and V12 of corn after soybean during 2008 to 2010

\begin{tabular}{|c|c|c|c|c|c|c|c|c|c|}
\hline \multirow[t]{2}{*}{ Growth stage } & \multirow[t]{2}{*}{ Model } & \multicolumn{2}{|c|}{2008} & \multicolumn{2}{|c|}{2009} & \multicolumn{2}{|c|}{2010} & \multicolumn{2}{|c|}{$\begin{array}{c}\text { Combined data } \\
(2008-2010)\end{array}$} \\
\hline & & $\mathrm{R}^{2}$ & Sig & $\mathrm{R}^{2}$ & Sig & $\mathrm{R}^{2}$ & Sig & $\mathrm{R}^{2}$ & Sig \\
\hline \multirow[t]{5}{*}{ V6 } & Linear & 0.78 & $* * *$ & & & 0.33 & $* *$ & 0.08 & Ns \\
\hline & Quadratic & 0.78 & $* * *$ & & & 0.34 & $*$ & 0.08 & $\mathrm{Ns}$ \\
\hline & Square root & 0.77 & $* * *$ & & & 0.33 & $* *$ & 0.08 & $\mathrm{Ns}$ \\
\hline & Logarithmic & 0.77 & $* * *$ & & & 0.34 & $* *$ & 0.07 & $\mathrm{Ns}$ \\
\hline & Exponential & 0.77 & $* * *$ & & & 0.32 & $*$ & 0.00 & $\mathrm{Ns}$ \\
\hline \multirow[t]{5}{*}{ V10 } & Linear & 0.83 & $* * *$ & 0.64 & $* * *$ & 0.60 & $* * *$ & 0.20 & $* * *$ \\
\hline & Quadratic & 0.89 & $* * *$ & 0.72 & $* * *$ & 0.62 & $* * *$ & 0.39 & $* * *$ \\
\hline & Square root & 0.82 & $* * *$ & 0.66 & $* * *$ & 0.59 & $* * *$ & 0.21 & $* * *$ \\
\hline & Logarithmic & 0.81 & $* * *$ & 0.67 & $* * *$ & 0.57 & $* * *$ & 0.23 & $* * *$ \\
\hline & Exponential & 0.87 & $* * *$ & 0.54 & $* * *$ & 0.62 & $* * *$ & 0.17 & $* * *$ \\
\hline \multirow[t]{5}{*}{ V12 } & Linear & 0.85 & $* * *$ & 0.76 & $* * *$ & 0.77 & $* * *$ & 0.32 & $* * *$ \\
\hline & Quadratic & 0.87 & $* * *$ & 0.79 & $* * *$ & 0.83 & $* * *$ & 0.38 & $* * *$ \\
\hline & Square root & 0.85 & $* * *$ & 0.77 & $* * *$ & 0.75 & $* * *$ & 0.33 & $* * *$ \\
\hline & Logarithmic & 0.84 & $* * *$ & 0.77 & $* * *$ & 0.74 & $* * *$ & 0.34 & $* * *$ \\
\hline & Exponential & 0.87 & $* * *$ & 0.69 & $* * *$ & 0.81 & $* * *$ & 0.28 & $* * *$ \\
\hline
\end{tabular}

$\dagger \mathrm{R}^{2}$, determination coefficient. Sig, significance.

$\ddagger^{*}, * *$, and $* * *$ significant at $0.05,0.01$, and 0.001 levels, respectively. Ns, not significant at 0.05 level. 
Table 4. Model comparisons in assessing the relationship of yield with plant height measured at V6, V10, and V12 of corn after cotton during 2008 to 2010

\begin{tabular}{|c|c|c|c|c|c|c|c|c|c|}
\hline \multirow[t]{2}{*}{ Growth stage } & \multirow[t]{2}{*}{ Model } & \multicolumn{2}{|c|}{2008} & \multicolumn{2}{|c|}{2009} & \multicolumn{2}{|c|}{2010} & \multicolumn{2}{|c|}{$\begin{array}{c}\text { Combined data } \\
(2008-2010)\end{array}$} \\
\hline & & $\mathrm{R}^{2}$ & Sig & $\mathrm{R}^{2}$ & Sig & $\mathrm{R}^{2}$ & Sig & $\mathrm{R}^{2}$ & Sig \\
\hline \multirow[t]{5}{*}{ V6 } & Linear & 0.53 & $* * *$ & & & 0.40 & $* *$ & 0.05 & Ns \\
\hline & Quadratic & 0.54 & $* * *$ & & & 0.55 & $* * *$ & 0.13 & Ns \\
\hline & Square root & 0.53 & $* * *$ & & & 0.42 & $* *$ & 0.06 & Ns \\
\hline & Logarithmic & 0.53 & $* * *$ & & & 0.43 & $* * *$ & 0.07 & Ns \\
\hline & Exponential & 0.51 & $* * *$ & & & 0.34 & $* *$ & 0.05 & Ns \\
\hline \multirow[t]{5}{*}{ V10 } & Linear & 0.60 & $* * *$ & 0.57 & $* * *$ & 0.68 & $* * *$ & 0.35 & $* * *$ \\
\hline & Quadratic & 0.61 & $* * *$ & 0.62 & $* * *$ & 0.68 & $* * *$ & 0.45 & $* * *$ \\
\hline & Square root & 0.60 & $* * *$ & 0.58 & $* * *$ & 0.68 & $* * *$ & 0.37 & $* * *$ \\
\hline & Logarithmic & 0.60 & $* * *$ & 0.59 & $* * *$ & 0.68 & $* * *$ & 0.39 & $* * *$ \\
\hline & Exponential & 0.61 & $* * *$ & 0.51 & $* * *$ & 0.65 & $* * *$ & 0.31 & $* * *$ \\
\hline \multirow[t]{5}{*}{ V12 } & Linear & 0.69 & $* * *$ & 0.70 & $* * *$ & 0.76 & $* * *$ & 0.43 & $* * *$ \\
\hline & Quadratic & 0.73 & $* * *$ & 0.70 & $* * *$ & 0.80 & $* * *$ & 0.47 & $* * *$ \\
\hline & Square root & 0.68 & $* * *$ & 0.70 & $* * *$ & 0.75 & $* * *$ & 0.44 & $* * *$ \\
\hline & Logarithmic & 0.67 & $* * *$ & 0.70 & $* * *$ & 0.73 & $* * *$ & 0.44 & $* * *$ \\
\hline & Exponential & 0.72 & $* * *$ & 0.67 & $* * *$ & 0.80 & $* * *$ & 0.38 & $* * *$ \\
\hline
\end{tabular}

$\dagger \mathrm{R}^{2}$, determination coefficient. Sig, significance.

$t^{* *}$ and $* * *$ significant at 0.01 and 0.001 levels, respectively. Ns, not significant at 0.05 level.

Table 5. Model comparisons in assessing the relationship of yield with plant height measured at V6, V10, and V12 of irrigated corn during 2008 to 2010

\begin{tabular}{|c|c|c|c|c|c|c|c|c|c|}
\hline \multirow[t]{2}{*}{ Growth stage } & \multirow[t]{2}{*}{ Model } & \multicolumn{2}{|c|}{2008} & \multicolumn{2}{|c|}{2009} & \multicolumn{2}{|c|}{2010} & \multicolumn{2}{|c|}{$\begin{array}{c}\text { Combined data } \\
(2008-2010)\end{array}$} \\
\hline & & $\mathrm{R}^{2}$ & Sig & $\mathrm{R}^{2}$ & Sig & $\mathrm{R}^{2}$ & Sig & $\mathrm{R}^{2}$ & Sig \\
\hline \multirow[t]{5}{*}{ V6 } & Linear & 0.69 & $* * *$ & & & 0.03 & $\mathrm{Ns}$ & 0.04 & $\mathrm{Ns}$ \\
\hline & Quadratic & 0.70 & $* * *$ & & & 0.03 & Ns & 0.26 & $* *$ \\
\hline & Square root & 0.69 & $* * *$ & & & 0.03 & $\mathrm{Ns}$ & 0.03 & Ns \\
\hline & Logarithmic & 0.68 & $* * *$ & & & 0.03 & Ns & 0.03 & Ns \\
\hline & Exponential & 0.70 & $* * *$ & & & 0.26 & $*$ & 0.05 & Ns \\
\hline \multirow[t]{5}{*}{ V10 } & Linear & 0.74 & $* * *$ & 0.44 & $* * *$ & 0.62 & $* * *$ & 0.51 & $* * *$ \\
\hline & Quadratic & 0.79 & $* * *$ & 0.47 & $* *$ & 0.62 & $* * *$ & 0.52 & $* * *$ \\
\hline & Square root & 0.73 & $* * *$ & 0.45 & $* * *$ & 0.62 & $* * *$ & 0.52 & $* * *$ \\
\hline & Logarithmic & 0.72 & $* * *$ & 0.45 & $* * *$ & 0.62 & $* * *$ & 0.52 & $* * *$ \\
\hline & Exponential & 0.78 & $* * *$ & 0.41 & $* * *$ & 0.61 & $* * *$ & 0.48 & $* * *$ \\
\hline \multirow[t]{5}{*}{ V12 } & Linear & 0.81 & $* * *$ & 0.55 & $* * *$ & 0.75 & $* * *$ & 0.51 & $* * *$ \\
\hline & Quadratic & 0.87 & $* * *$ & 0.57 & $* * *$ & 0.75 & $* * *$ & 0.54 & $* * *$ \\
\hline & Square root & 0.80 & $* * *$ & 0.55 & $* * *$ & 0.75 & $* * *$ & 0.52 & $* * *$ \\
\hline & Logarithmic & 0.79 & $* * *$ & 0.56 & $* * *$ & 0.75 & $* * *$ & 0.53 & $* * *$ \\
\hline & Exponential & 0.86 & $* * *$ & 0.52 & $* * *$ & 0.74 & $* * *$ & 0.48 & $* * *$ \\
\hline
\end{tabular}

$\dagger \mathrm{R}^{2}$, determination coefficient. Sig, significance.

$\ddagger^{*}, * *$, and $* * *$ significant at $0.05,0.01$, and 0.001 levels, respectively. Ns, not significant at 0.05 level. 


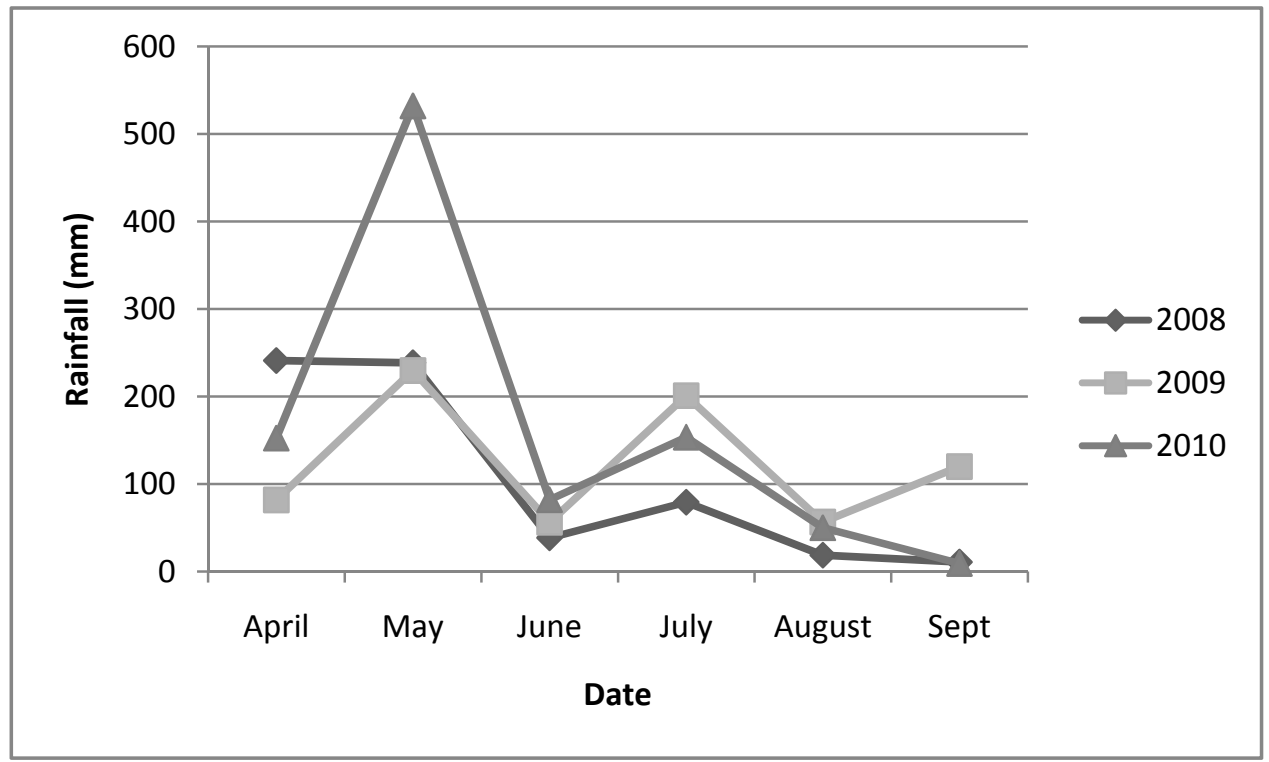

Figure 1. Rainfall of the growing season in 2008, 2009, and 2010 at Milan, TN

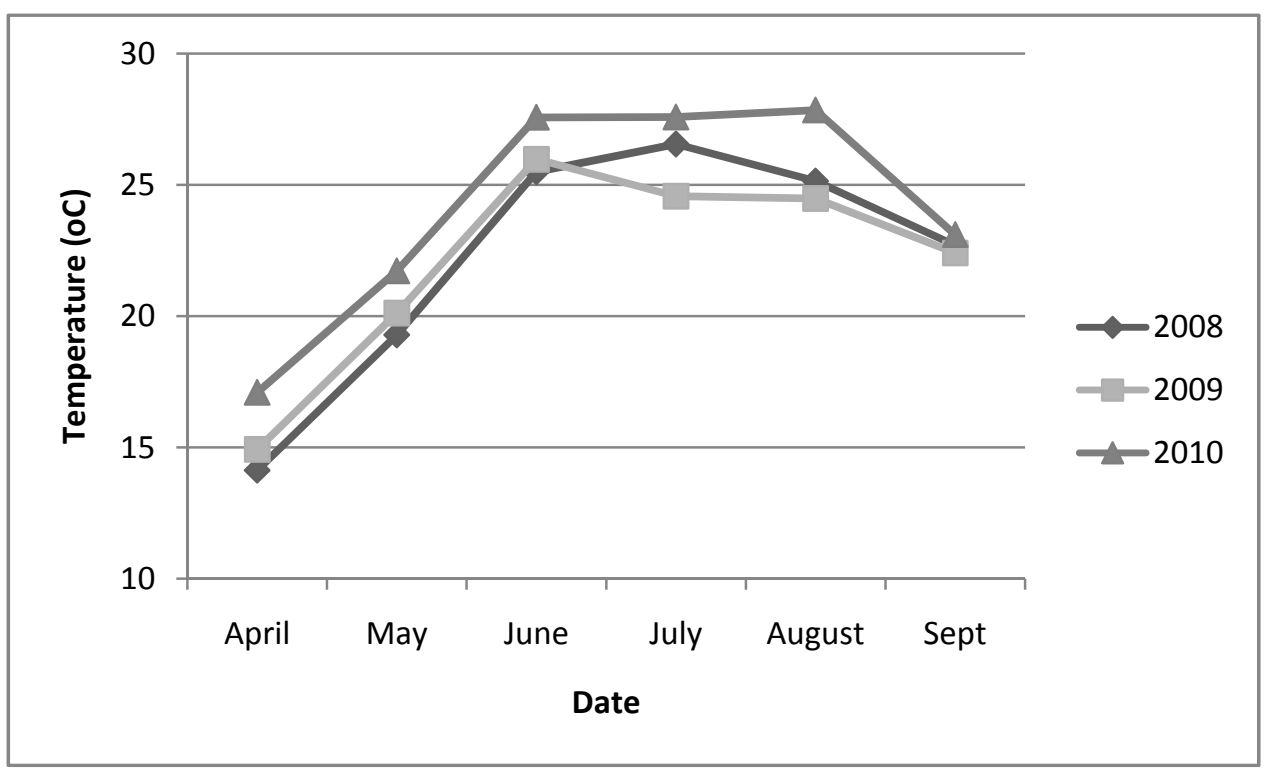

Figure 2. Air temperature of the growing season in 2008, 2009, and 2010 at Milan, TN 


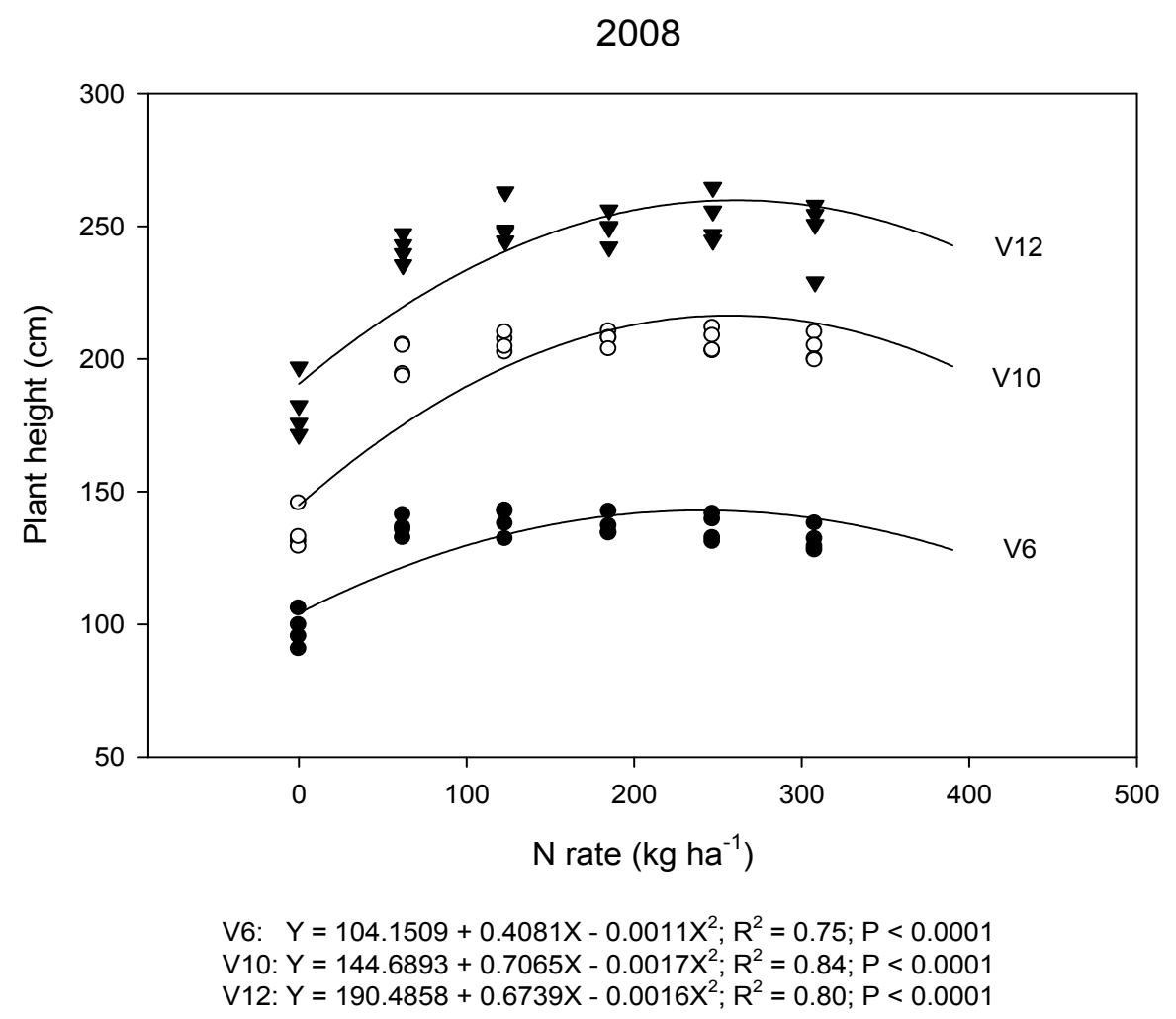

Figure 3. Relationship of plant height measured at V6, V10, and V12 with $\mathrm{N}$ application rate in corn after soybean in 2008

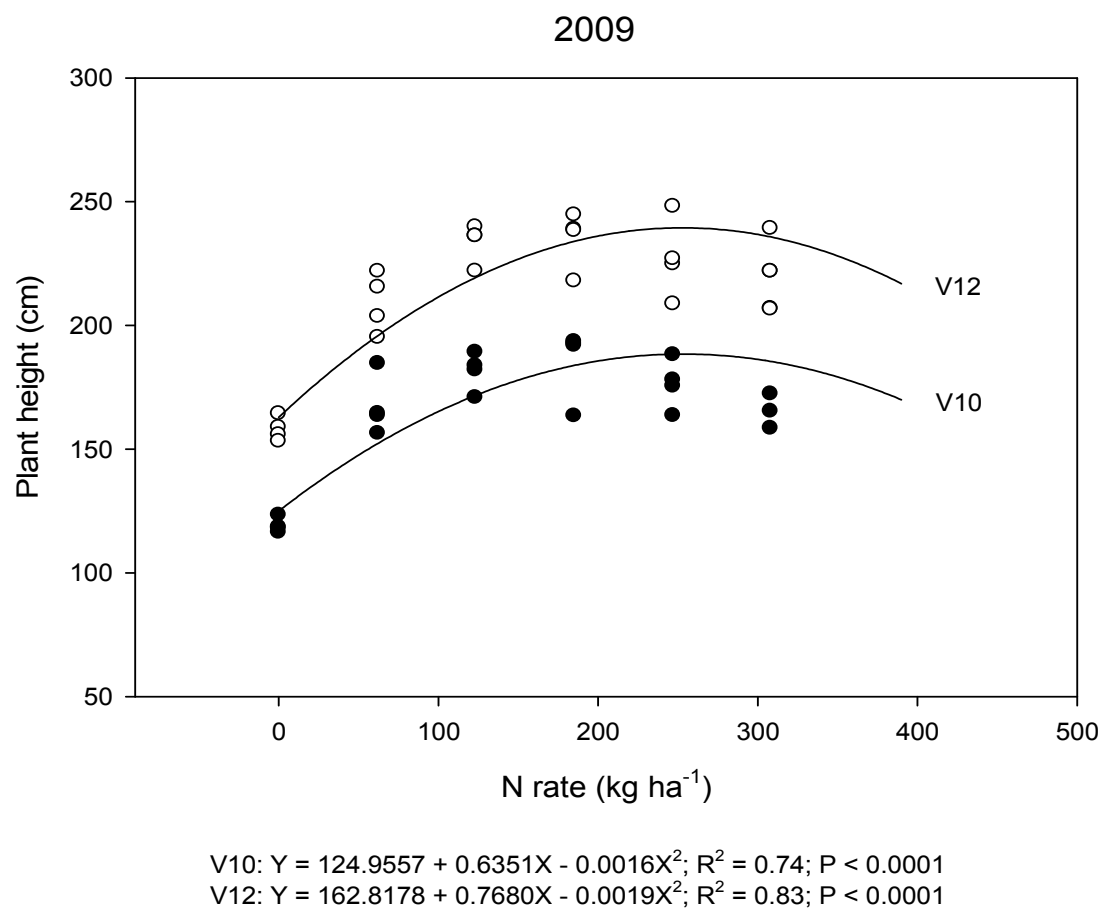

Figure 4. Relationship of plant height measured at V10 and V12 with $\mathrm{N}$ application rate in corn after soybean in 2009 


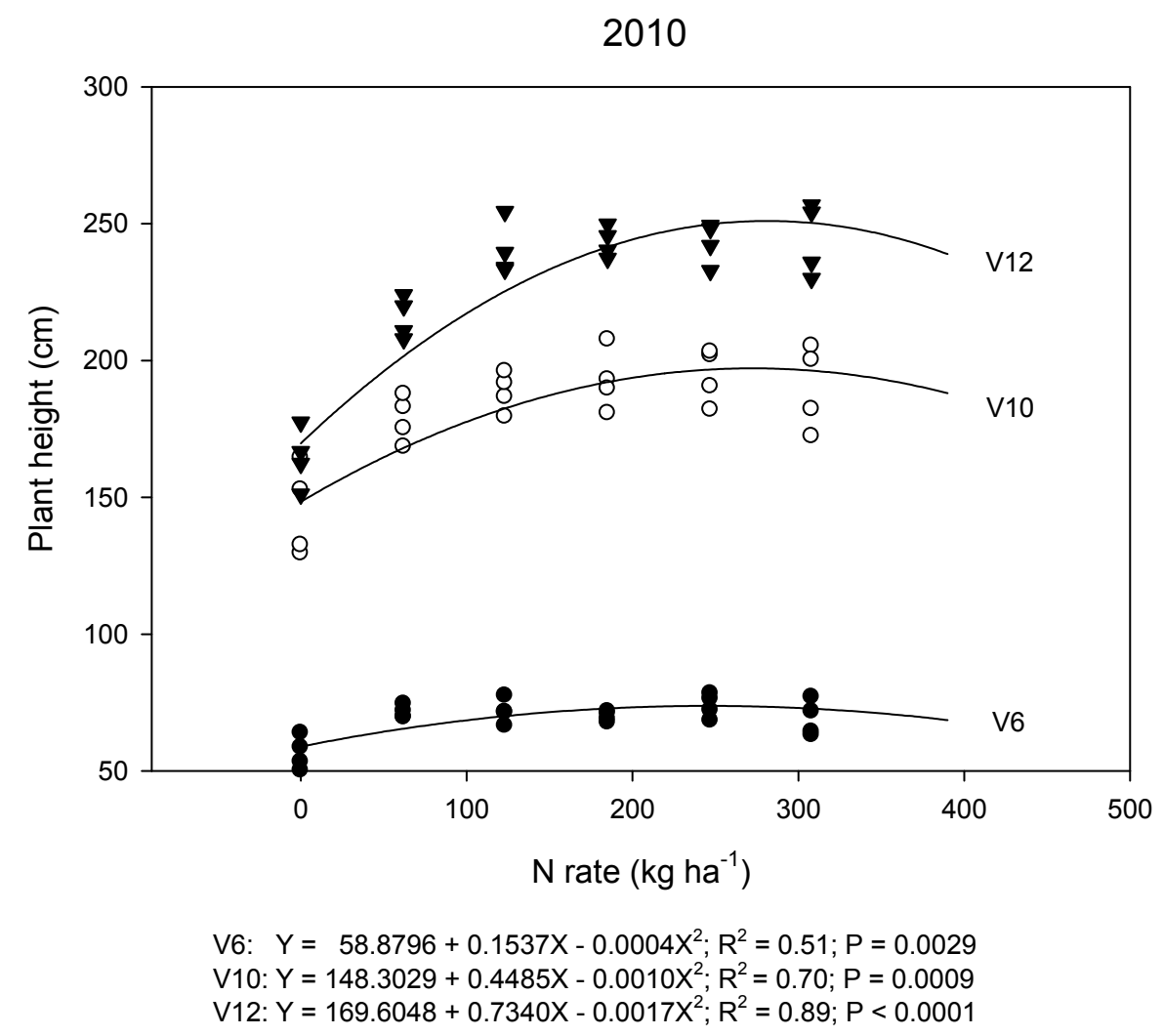

Figure 5. Relationship of plant height measured at V6, V10, and V12 with N application rate in corn after soybean in 2010 